KANT. Immanuel. Antropologia de um ponto de vista pragmático. São Paulo: Iluminuras, 2006.

Crítica da razão pura. São Paulo: Abril Cultural, 1980 (Os pensadores).

MICHAELIS. Dicionário escolar língua portuguesa. São Paulo: Melhoramentos, 2008.

MORRIS, Charles (1976). Fundamentos da teoria dos signos. Traduzido por Milton José Pinto. Revisão técnica por Nicolau Salum. Rio de Janeiro: Eldorado Tijuca; São Paulo: Editora da Universidade de São Paulo.

TAVARES, Amanda Savioli Marques. Fotografia e memória: instrumentos de documentação e criação. Leituras do Jornalismo, v. 2, n. 3, p. 142, 2015. Disponível em:http://www2.faac.unesp.br/ojs/index.php/leiturasdojornalismo/article/view/55.

Acessado em: 30 set. 2015.

\title{
Nietzsche e a educação: Schopenhauer como exemplo de educador
}

Luciana Vieira de Lima67

Resumo: Este artigo tem como propósito elaborar uma análise das críticas feitas por Nietzsche à educação e à cultura alemã de sua época, tendo, como fonte a terceira Consideração Extemporânea, intitulada: Schopenhauer Educador. Neste texto, Nietzsche faz um diagnóstico de que existiam três tendências no modelo educacional, que impossibilitavam o desenvolvimento de uma cultura autêntica: uma educação que visava apenas a instrução, a formação de homens dóceis e úteis, e, por último, a questão do eruditismo entre os professores; orientações que serviriam somente ao interesse do Estado, que buscava lucro e propriedade por intermédio de uma pseudocultura. Neste contexto, tanto a educação quanto a formação estavam subordinadas aos interesses do Estado. Contrapondo-se a esta concepção, Nietzsche vê a necessidade de que a educação e a formação tenham educadores que sejam modelos e exemplos, virtudes que Nietzsche encontrou em Schopenhauer, por ele não estar em consonância com os valores vigentes de sua época, pois só assim se pode pensar em uma cultura autêntica.

Palavras-chave: Nietzsche. Cultura. Educação. Schopehauer.

\section{Nietzsche and Education: Schopenhauer as an example of Educator}

Abstract: This article aims to elaborate an analysis of the criticisms made by Nietzsche to the education and the German culture of his time having as source the Untimely Meditations III: Schopenhauer as Educator. In this text Nietzsche makes a diagnosis that there were three tendencies in the educational model that prevented the development of an authentic culture: an education that aimed only at education, the formation of docile and useful men, and finally, the question of eruditism among teachers; Guidelines that would serve only the interest of the State, which sought profit and ownership through a pseudoculture. In this context, both education and training were subordinated to the interests of the State. Contrary to this view, Nietzsche sees the need for education and training to have educators who are models and examples, virtues that Nietzsche found in Schopenhauer because he is not in agreement with the current values of his time, because only in this way is it possible to think of an authentic culture.

Key Words: Nietzsche. Culture. Education. Schopehauer.

\footnotetext{
${ }^{67}$ Mestra (PUC PR). Doutoranda em Educação Filosófica (UFPR). Professora de Filosofia da Faced - Curitiba. Email:Iuna_lima@hotmail.com
} 
Submetido em: janeiro de 2016. Aprovado em: março de 2016.

\section{Introdução}

Friedrich Wilhelm Nietzsche escreveu, entre os anos de 1873-76, quatro textos, intitulados de Considerações Extemporâneas, sendo a primeira: David Strauss o confessor e o escritor; a segunda: Da utilidade e desvantagem da história para a vida; a terceira: Schopenhauer como educador; a quarta e última: Wagner em Bayreuth. Textos estes que podem ser lidos e interpretados individualmente ou analisados como um projeto crítico a respeito da cultura da época do filósofo.

Este artigo abordará a crítica nietzschiana a respeito da cultura e terá seu foco na Terceira Extemporânea, perpassando pela análise dos conceitos de formação (Bildung) e de educação (Erziehung) dos alemães modernos para uma melhor compreensão do motivo de a cultura estar enfraquecida. Para Nietzsche, a educação necessita de modelos de educador, como o de Arthur Schopenhauer, que representava a contraposição aos eruditos de sua época que nada mais eram que filisteus da cultura ${ }^{68}$. Desta maneira, buscar-se-á apresentar as características que fazem de Arthur Schopenhauer um modelo do educador autêntico, também será apresentada a crítica nietzschiana ao sistema educacional com o enfoque para as instituições superiores de ensino e das universidades alemães da época, para, em seguida, apresentar Schopenhauer como modelo de mestre e de filósofo, pois não ensina apenas com seus conhecimentos acumulados, mas também com seu modelo de vida.

Para Nietzsche, era necessário que se repensasse o papel dos professores de filosofia na universidade e a sua relação com o Estado, pois eles só fazem uma reprodução da história da filosofia, sem estimular o pensamento crítico e o debate dos problemas postos naquele momento, propagando uma pseudocultura, que levava a uma impressão falsa de possuírem uma cultura autêntica.

\footnotetext{
${ }^{68}$ A palavra <<filisteu>> é tomada como se sabe da vida estudantil e usada em seu sentido mais amplo [...], em contraposição aos filhos das musas, dos artistas, dos autênticos homens da cultura. Os filisteus da cultura, no entanto, [...] se diferenciam da ideia universal do gênero <<filisteu〉> por uma crença supersticiosa: o filisteu da cultura possui a ilusão de ser ele mesmo o filho das musas e um homem de cultura; ilusão inconcebível, da qual se desprende que ele nem mesmo sabe, em absoluto, o que é um filisteu e o que é sua antítese: por isso não devemos nos surpreender, se ele, na maioria dos casos, jure solenemente não ser filisteu. (NIETZSCHE, 2000, p.35, tradução nossa).
} 


\section{Nietzsche e a crítica ao sistema educacional de sua época}

Nietzsche elabora uma crítica em relação à cultura (Kultur) de sua época, contrapondo-a ao que seria uma cultura autêntica ${ }^{69}$, para tanto é preciso analisar a questão da educação (Erziehung) e da formação (Bildung), pois não se pode pensar em uma cultura autêntica sem avaliar estes dois conceitos, já que são eles que podem consolidá-la ou enfraquecê-la. Para Nietzsche (2005, p.168), a cultura de sua época era apenas,

um tipo de saber sobre a cultura, e além disso um saber muito falso e superficial, na medida em que mantinha a contradição entre a vida e o conhecimento, e era cego para aquilo que caracterizava a cultura dos povos verdadeiramente civilizados: o fato de que a cultura não pode crescer e florescer senão na medida em que esteja enraizada na vida.

Em Schopenhauer como educador, Nietzsche busca analisar tanto a formação quanto a educação dos alemães de sua época, pois o modelo educacional concernente ao da crítica nietzschiana se sustentava no eruditismo que produzia apenas passividade e conformismo intelectual no discente, transformando-o em uma pessoa obtusa e superficial.

Um dos fatores da crise da cultura alemã estaria no seu modelo educacional de formar, tanto intelectual, quanto existencialmente, indivíduos para executarem funções técnicas, ou seja, funções especializadas, não visando a um estímulo para a criação e para a vida. Ao criticar o modelo educacional de sua época, o filósofo pontuou alguns problemas deveras importantes, são eles: a educação, que visa apenas à instrução; o fato de o Estado sobrepor seus interesses ao sistema educacional, passando a ser o fim supremo para qualquer forma de conhecimento; e o de que os educadores alemães seguiam a tendência eruditista.

A respeito do primeiro problema, o filósofo apontava que o modelo educacional buscava instruir apenas seus alunos em prol do mercado de trabalho, neste modelo a educação oferecida deveria ser "rápida, para se tornar logo um ser que ganha dinheiro" (NIETZSCHE, 2003, p.186), tendo como fórmula o máximo de conhecimento possível. Apesar disto, o objetivo era alcançar mais produção e ganhos, gerando uma falsa noção

\footnotetext{
${ }^{69}$ Para Nietzsche (2005, p.178), a cultura autêntica "vê em si uma nova e melhor fhysis, sem distinção de um interior e de um exterior, sem dissimulação e sem convencionalismo: a concepção de uma cultura que se realiza o acordo entre vida e pensamento, entre a aparência e o querer.".
} 
de bem-estar, conduta que negligenciava a vida, pois os conhecimentos adquiridos estavam direcionados ao imediatismo da prática do saber-fazer, não levando o aluno a um conhecimento que o estimulasse à vida, e, também, não o fazia crescer intelectualmente, já que este modelo educacional primava pelo saber quantitativo. $\mathrm{O}$ objetivo deste modelo, segundo Nietzsche, era propiciar ao homem ganhar dinheiro. Assim, a educação se reduziria a:

Formar o maior número possível de homens correntes, no sentido de que se fala de moeda corrente, este seria o objetivo; e segundo esta concepção, um povo seria cada vez mais feliz, na medida em que possuísse mais estes homens correntes. Assim também, a intenção dos estabelecimentos modernos de ensino devia ser a de levar cada um, na medida em que isto está na sua natureza, a de reproduzir o modelo "corrente" e a de educar de tal maneira, que se extraia do seu grau próprio de conhecimento e saber a maior quantidade possível de felicidade e lucro. (NIETZSCHE, 2003, p.186).

Portanto, para o filósofo, o modelo educacional alemão caminhava no sentido oposto do que seria de fato uma cultura autêntica, já que este modelo se pautava nas necessidades mercadológicas que requeriam apenas a maior especialização possível, restrita, em determinada área de conhecimento para atuação profissional mais qualificada e eficiente.

Para atender a esta demanda, os estabelecimentos educacionais da época proporcionavam o maior número possível de especialistas úteis à economia "no interesse do lucro geral e do comércio mundial" (NIETZSCHE, 2003, p.186). O principal sintoma desta educação para o jovem estudante é o de fomentar nele que o conhecimento está relacionado ao ganho de dinheiro, é como se a vida não lhe oferecesse outra coisa, ficando suprimida, deixando a entender que a cultura que o estudante buscava era apenas aquela que estava submetida ao mercado. Esta postura dava a sensação, para os alemães, de existir uma simetria entre educação e cultura, porque tanto os eruditos quanto os filisteus da cultura disseminavam esta conduta.

O segundo problema reside em "como o Estado não pode promover um outro interesse na universidade, senão o de fazer educar através dela os cidadãos devotados e úteis" (NIETZSCHE, 2003, p.218), não havendo outro objetivo do Estado a não ser formar homens que lhe sejam dóceis e convenientes. Daí a sua vontade em universalizar a educação, ocasionando um enfraquecimento da cultura, sendo o Estado, para os alemães modernos, "o fim supremo da humanidade e que não há para o homem deveres mais elevados do que servir ao Estado (NIETZSCHE, 2003, p.165). Nietzsche 
enxergava, neste comportamento, uma ausência de necessidades mais elevadas do que o dever para com o Estado que, para o filósofo, tal conduta não exime a possibilidade de existir outros homens e outros deveres. Segundo ele, estes homens seriam os filósofos, que conseguiriam perceber que existe um mundo além do bem do Estado e que não veem nele um fim supremo. Neste contexto, Nietzsche também criticava a filosofia universitária e os seus professores, questionando qual era a relação da filosofia com o Estado:

\begin{abstract}
O incentivo dado à filosofia consiste então unicamente em que, em nossos dias, o Estado permite, pelo menos a um certo números de homens, a viver de sua filosofia, fazendo dela seu ganha-pão; enquanto que os antigos sábios da Grécia, longe de serem subvencionados pelo Estado, eram quando muito honrados, às vezes, como Zenão, com uma coroa de ouro ou um monumento funerário no Cerâmico. (NIETZSCHE, 2003, p.165, grifo do autor).
\end{abstract}

Deve-se notar que a critica nietzschiana, tanto para a filosofia quanto para seus docentes, é em relação à subserviência deles para com o Estado, pois Este não estava preocupado com a questão da formação em si, a não ser, enquanto ela fosse útil a Ele. Deste modo, parecia ser conveniente, tanto para o Estado quanto para os filósofos, em questão, validarem a cultura como mantenedora do bem do Estado. Já, aqueles que Nietzsche define como filósofos de profissão tratavam este conhecimento como meio de subsistência ou como meio de se obter prestígio social, e eles, por sua vez, acabavam produzindo uma pseudofilosofia, pois estes homens "perderam o último vestígio não somente de todo o pensamento filosófico, [...], em troca, o que adquiriram não foi o otimismo, mas antes o jornalismo, o espírito - e a ausência de espírito - da atualidade e dos jornais" (NIETZSCHE, 2003, p.164), estes homens se preocupavam mais com os acontecimentos políticos do que com a questão existencial, todavia os filósofos autênticos devem estar mais empenhados em ocupar-se com os enigmas existenciais do que buscar, no magistério, admiração por parte de seus colegas e da sociedade. Assim, Nietzsche (2003, p.209), nos fornece o exemplo de Emmanuel Kant, que se "mostrava respeitoso, servil e sem grandeza nas suas relações com o Estado"; e, portanto, a filosofia que era produzida na universidade em sua época deveria ser repensada, porque o Estado tinha medo do verdadeiro filósofo e da filosofia, "então, neste caso, ele buscará, cada vez mais, atrair para si o maior número de filósofos que puder, o que lhe confere a ilusão de ter a filosofia do seu lado, - e assim estes homens que se valem dela" (NIETZSCHE, 2003, p.210). Neste sentido, o Estado só favoreceria os filósofos que não lhe causassem nenhum incômodo.

Para Nietzsche, os filósofos autênticos não deveriam fazer nenhum tipo de 
concessão para o Estado, devendo-se colocar acima dele mesmo "que eles sejam perseguidos, que se olhe para eles com descrédito" (NIETZSCHE, 2003, p.217) em vez de aceitar receber um salário, rendendo-se a seus caprichos sem nada contestar.

No que se refere ao terceiro problema: a questão do eruditismo, entre os professores encontram-se os do tipo erudito que se manifestavam na figura intelectual, que abria mão de qualquer experiência criativa em favor do conhecimento abstrato, desvencilhado totalmente da vida. O erudito não possuía a força plástica ${ }^{70}$ para transformar seus conhecimentos em ação, ele era o homem que queria conhecer a qualquer custo, quanto mais conhecimento, melhor. A crítica é que esta forma de conhecimento só se sustenta no campo teórico, transformando-se em algo superficial e artificial, comprometendo a formação dos alunos e, em consequência, o da própria cultura.

O erudito "representa o nanismo intelectual, o ir daqui para lá consultando livros mas sem conseguir nunca 'receber uma impressão insólita ou ter um pensamento decente', o falar dos livros, mas sem saber escutar o que têm para dizer" (LARROSA, 2005, p.37). Neste âmbito, o saber do erudito é limitado e superficial, pois ele simboliza a divisão do trabalho das ciências, parecendo um operário de fábrica que só sabe executar uma parte do todo, mas que de maneira incontestável chega ao momento de fazê-lo com primor. Assim o erudito, segundo Nietzsche, seria pernicioso para a educação, pois só consegue promover os mesmos modelos em que foi formado e é na prática habitual que "escolhe os livros com os quais sente uma certa afinidade" (NIETZSCHE, 2003, p.194), distanciando-se do que não se assemelha a sua forma de pensar, se dispondo

\begin{abstract}
à verdade, quando está em condições de fornecer diretamente gratificações e progressões na carreira, ou pelo menos quando está em condições de conquistar o favor daqueles que distribuem o pão e as honras. Mas, assim, somente se serve a esta verdade: esta é a razão porque uma fronteira se instaura entre as verdades lucrativas, que muitos úteis, e as verdades que não são exploráveis: aquelas que só podem ser oferecidas pelos raros, a respeito dos quais não se pode dizer: ingenii largitor venter ${ }^{71}$. (NIETZSCHE, 2003, p.195, grifo do autor).
\end{abstract}

Neste sentido, quem estabelece uma certa adaptação das ações dos eruditos para com seus objetivos seria o Estado. Assim, segundo Nietzsche, estas seriam verdades

\footnotetext{
${ }^{70}$ Para Nietzsche $(2005$, p.73), a força plástica é o que "permite a alguém desenvolver-se de maneira original e independente, transformar e assimilar as coisas passadas ou estranhas, curar as sua feridas, reparar as suas perdas, reconstituir por si próprio as formas destruídas".

${ }^{71}$ Em latim significa "seu ventre é o provedor do seu espírito". (NIETZSCHE, 2003, p.195).
} 
produtivas e rentáveis, a eles e às intuições as quais pertenciam, já que os eruditos educadores eram funcionários do Estado e assim sendo eram os mantenedores da ordem vigente, desconsiderando qualquer educação que visasse a uma formação crítica. Segundo Melo Sobrinho (2003), o erudito é uma contradição, pois, ao mesmo tempo em que é motivado por um instinto de conhecimento, possui uma determinada urgência em adquiri-lo, não alcançando uma visão mais ampla do real, não percebendo, assim, o quão controverso ele o é, por desejar, a qualquer custo, uma certeza.

O filósofo também percebeu que os valores da cultura moderna eram o cume da barbárie e da mediocridade, já que a cultura moderna alemã exaltava o Estado, a igreja e a ciência como especialidade do conhecimento, "em detrimento da experiência interior de um pensamento solitário, criador e exemplar, como deve ser a do filósofo" (MELO SOBRINHO, 2003, p.16), perpassando, assim, para o âmbito da educação, que sacramentava os estudantes em uma erudição falsa e superficial, pois estava a serviço dos interesses do Estado. Assim, os eruditos alemães pensavam mais na ciência do que na humanidade, fazendo dela um comércio: "O comércio com a ciência, quando não é orientado e delimitado por uma máxima superior de educação, mas sempre mais desencadeado, segundo o princípio 'quanto mais, melhor'” (NIETZSCHE, 2003, p.144), sendo que a ciência "dá a eles o comportamento indiferente das mercadorias fabricadas em série [Fabrikwaare], indignas de contato e de ensino" (NIETZSCHE, 2003, p.139).

Outro ponto importante a ser destacado, na Terceira Consideração Extemporânea, é o de Nietzsche sugerir a implantação de um tribunal que analise a cultura transmitida e desenvolvida nas universidades da Alemanha, afirmando que, quem melhor desempenharia essa função seria a filosofia, desde que ela não tivesse seus poderes confiscados pelo Estado, pois, para ele, a filosofia é o centro da compreensão a respeito da vida.

Nietzsche ainda sublinhou que somente o homem que, com seu olhar abrangeu o quadro geral da vida e da existência, poderia, então, se servir das ciências em particular, sem se deixar por elas ser prejudicado; ao contrário, sem essa "imagem reguladora de conjunto, elas são apenas fios que, no final, não levam a lugar nenhum e tornam o curso de nossa vida mais confuso e mais labiríntico" (NIETZSCHE, 2003, p.157). Neste âmbito, é preciso colocar-se "diante da imagem da vida como diante de uma totalidade, para interpretá-la como totalidade" (NIETZSCHE, 2003, p.156) e não como fazem os homens da ciência que, para tentar entendê-la dividem-na em partes, deixando escapar o 
essencial, que é o olhar abrangente que traz em seu bojo a dúvida e a crítica, e não deixa os problemas humanos se esvaírem como fazem os cientistas, que diante de um quadro examinam detalhadamente as cores [...] e a matéria sobre a qual ele é pintado; tendo como resultado talvez que se trata aí de um véu com uma textura particularmente sutil e que as cores aí colocadas não podem ser analisadas quimicamente. (NIETZSCHE, 2003, p.156).

Desta maneira, segundo o filósofo, o homem da ciência deixou escapar o essencial, o aspecto humano; ou seja, o homem por trás do quadro: "é preciso imaginar o pintor caso, se queira conhecer o quadro" (NIETZSCHE, 2003, p.156).

Nas Extemporâneas, Nietzsche encontrou, na educação e na formação, os obstáculos para o surgimento de uma cultura autêntica. Como, então, esses fatores podem contribuir para o florescimento dessa cultura, já que são eles a base para uma cultura autêntica?

Contra o modelo educacional de sua época, que teria sucumbido aos interesses dos negócios e do Estado, levando a cultura à degeneração, o filósofo então, busca um modelo de educador, para que com ele possa nascer uma cultura autêntica.

\footnotetext{
Nietzsche toma para si a questão do destino da humanidade, que ele vê correr o maior perigo em vista das condições modernas nas quais os homens estavam inseridos. A "revolução atômica" que dissolve as velhas tradições se avizinha celeremente, mas, enquanto ela não chega, diz Nietzsche, é que o perigo para o homem é maior: cultiva-se a animalização do homem, a idolatria do Estado como fim supremo da humanidade e da propriedade como sinônimo de felicidade, através dos estabelecimentos de ensino e a cultura jornalística [...] Nestas circunstâncias delicadas e quase extremas, como seria ainda possível libertar pelo menos os mais bem dotados através da educação? Eis a questão que Nietzsche quer responder, chamando atenção para a intempestividade de Schopenhauer (MELO SOBRINHO, 2003, p.17).
}

A educação deve se empenhar em formar um homem criativo, crítico e que seja, ao mesmo tempo, livre dos interesses do Estado, para tanto, é preciso que os educadores estejam em consonância com esse propósito, daí o princípio nietzschiano de "educar os educadores", ou seja, no processo educacional do homem é preciso ao educador educarse a si mesmo.

Então qual seria a tarefa do verdadeiro educador? Para Nietzsche, consiste primeiramente em "transformar todo homem num sistema solar e planetário" (NIETZSCHE, 2003, p.143) e que revele a vida, para poder, assim, descobrir "a lei da sua mecânica superior" (NIETZSCHE, 2003, p.143), para que esse educador não se deixe levar por interesses que dissimulam a vida.

Os filósofos a que Nietzsche se dedica são aqueles que, para ele, não se 
renderam aos caprichos e imposições do Estado, pois são fiéis ao seu próprio pensar e não se deixam levar pelas ciências praticadas em prol do Estado, "sem medida e abandonadas ao mais cego laissez-faire” (NIETZSCHE, 2003, p.166). Para o filósofo, "as classes cultas e os Estados civilizados são arrastados por uma corrente de dinheiro gigantesca e desprezível” (NIETZSCHE, 2003, p.166), o homem culto se degenerou, deixando tudo a serviço "da barbárie que vem vindo, tudo, aí incluídas a arte e a ciência desta época" (NIETZSCHE, 2003, p.166); e, ao se degenerar, este homem que era culto, tornou-se a maior ameaça para a cultura, pois ele nega que a cultura esteja doente e degenerada, porque traz consigo uma alegria artificial por "dissimular a felicidade" (NIETZSCHE, 2003, p.166), fazendo desta alegria algo que chega a comover, fato totalmente inconcebível para o filósofo alemão.

\section{O exemplo de educador para Nietzsche}

Vale retomar que, nesta perspectiva de análise, somente por meio da educação há a possibilidade de uma cultura autêntica, e isso só será possível quando a educação deixar de ser mera transmissão e instrução de conhecimentos e passar a ter educadores que incentivem a vida por meio de seus exemplos e modelo pessoal de vida, antes de tudo.

Para Nietzsche, tanto o "exemplo", quanto o "modelo" do filósofo diante da sua vida e não apenas o seu conhecimento fará dele um verdadeiro educador, assim, a tarefa educativa se constituiria principalmente pelo exemplo e não apenas pelo acúmulo de conhecimento, sendo ele aquele que impulsiona o desenvolvimento crítico e a atividade criadora individual. Na Terceira Extemporânea, Nietzsche coloca Arthur Schopenhauer como exemplo desse filósofo educador, que poderia ser tomado como um mestre, pois ele conseguiu como poucos "legislar" sobre sua vida e seu pensamento. Ao apresentar Schopenhauer como o modelo a ser seguido, Nietzsche iniciou seu texto relatando como fora para si próprio a busca por um mestre, demonstrando como buscou autoeducar-se. Ele ainda relata a sua necessidade de encontrar um referencial, um mestre que servisse de modelo para seu projeto, que era: o de criticar os princípios e a visão dominante nas instituições e nos meios acadêmicos da Alemanha de sua época. A respeito de sua busca, ele relata:

No entanto, este filósofo me faltava e eu experimentava ora uma coisa ora outra; ponderava que figura mesquinha éramos nós, homens modernos, diante dos Gregos e dos Romanos, quer fosse mesmo em relação à seriedade 
ou à severidade na concepção das tarefas da educação. Com esta necessidade em mente, se pode percorrer toda a Alemanha, e todas as universidades em particular, mas não se encontrará o que se procura; por outro lado, muitos desejos mais simples e mais elementares não encontraram aí satisfação (NIETZSCHE, 2003, p.144).

Neste particular, Nietzsche nos alerta que a procura por um verdadeiro mestre filósofo - não é uma tarefa fácil e que o lugar menos provável para encontrá-lo seria nas universidades ou nos estabelecimentos de ensino, já que estes lugares estavam repletos de eruditos; porque o verdadeiro educador caminha contra o conformismo das opiniões vigentes, da banalidade da cultura jornalística e de qualquer forma de poderes estabelecidos, pois ao olharmos para os gregos e romanos poderíamos perceber que os modernos suprimiram qualquer forma de educação que promovesse novas ideias. (NIETZSCHE, 2003).

A procura de Nietzsche por um mestre teve seu termo em 1865, quando ele mudou para Leipzig e ali encontrou, em um antiquário, a obra de Arthur Schopenhauer: O mundo como vontade e representação. Sobre o filósofo de Frankfurt, Nietzsche escreve: "É por isso que vou lembrar hoje o nome do único professor, o único mestre de quem eu posso me orgulhar, Arthur Schopenhauer, para só me lembrar de outros mais tarde" (NIETZSCHE, 2003, p.142, grifo do autor). Assim, Nietzsche expõe como foi importante para ele seu primeiro olhar nos escritos de Schopenhauer,

é preciso que me detenha um pouco numa imagem que me preocupou incontestavelmente na juventude, mais freqüentemente e mais decisivamente do que qualquer outra. Quando outrora eu me entregava, por vontade própria, a fazer minhas promessas, imaginava que o terrível esforço, o tremendo dever de me educar a mim próprio, me seria poupado pelo destino, porque no momento propício encontraria um filósofo para me educar. (NIETZSCHE, 2003, p.142).

Quando Nietzsche defende a necessidade de educadores genuínos, significa que o homem que os deseja encontrar, precisa, por si mesmo, buscá-los e não esperar que eles lhe sejam oferecidos; o indivíduo deve almejar um crescimento integral e harmonioso de todas suas faculdades, estando disposto a se esforçar ao máximo e colocando a busca por um mestre como um dever. Ainda, nesta perspectiva, Nietzsche acrescenta que esta busca deve ser para encontrar o "verdadeiro filósofo a quem se pudesse obedecer sem mais reflexão, porque se teria nele mais confiança do que em si próprio" (NIETZSCHE, 2003, p 142), que para ele era Schopenhauer. A este respeito, 
cabe aqui destacar que existe um consenso entre alguns de seus comentadores ${ }^{72}$ sobre a forte influência de Schopenhauer nos primeiros escritos nietzschianos; mas, apesar disto, Paschoal (2008) salienta que, mesmo sendo influenciado pelo pensamento de Schopenhauer, não se deve ignorar que, em alguns momentos, Nietzsche não segue seu mestre, ele apenas se utiliza da filosofia schopenhaueriana para gerar propósitos distintos daqueles cogitados pelo filósofo de Frankfurt.

\begin{abstract}
A cada momento, a cada nova construção argumentativa, eles são tomados como fios utilizados para tecer novas teias. São, portanto, instrumentos e não conceitos ou posições fixas que uma vez explicitados, exigiram a fidelidade do filósofo (PASCHOAL, 2008, p.340).
\end{abstract}

Então, contra o ideal vigente em sua época, Nietzsche coloca a figura de Schopenhauer como modelo de um verdadeiro educador, ele encontra, neste filósofo, um exemplo de vida antes de tudo, o que nele habita é a sua vida e não somente seu conhecimento, e a autêntica educação deve partir desse princípio. Portanto, a partir deste ponto, buscar-se-á apontar as características que fazem de Schopenhauer um educador autêntico.

Schopenhauer é um modelo que educa, porque estabelece responsabilidades e deveres para si, mostrando que existe a possibilidade de um sentido para a vida. Um dos primeiros ensinamentos que ele legou foi sobre o perigo que sempre rondou sua vida, na intenção de desviar sua atenção para outros fins que não fossem a sua filosofia. Destarte, Nietzsche apresenta três perigos que estiveram à sombra na vida de Schopenhauer; estes perigos representam a exposição de um homem às mazelas de seu tempo que poderiam lhe corromper, desencorajar ou desviar do caminho que se desejava.

O primeiro perigo foi a solidão, ele foi um homem solitário, pois abdicou-se da promessa de felicidade coletiva para salvaguardar a integridade de sua filosofia e também a sua própria, assim o filósofo de Frankfurt não sucumbiu à maldição, pois "há sempre, em toda solidão, uma culpa secreta" (NIETZSCHE, 2003, p.153). Ele não via, segundo Nietzsche, nenhum problema nisso, pois não se sentia culpado e encontrava na solidão a única forma de vida consonante com o espírito filosófico. O segundo foi o desespero da verdade, pois Schopenhauer teria começado a carreira a partir da filosofia

\footnotetext{
${ }^{72}$ A título de exemplo, ver: MACHADO, R. Nietzsche e a polêmica sobre o nascimento da tragédia. Rio de Janeiro: Jorge Zahar, 2005, p.26 e JANZ, C. P. Friedrich Nietzsche: infância y juventud. Tradução de: MUÑOZ, Jacobo. Madrid: Alianza Editorial, 1981,v.1. p.211-212.
} 
kantiana, mas não cedeu ao seu ceticismo, mesmo encontrando na filosofia de Kant alguma dificuldade, pois, esta demandava força de pensamento e atenção de seu leitor. A respeito de Kant, Nietzsche afirmou que o pensamento kantiano é fecundo apenas em um "homem robusto e completo no sofrimento e no desejo, e não simplesmente uma ruidosa máquina de pensar e calcular" (NIETZSCHE, 2003, p.155), aquilo que levaria outros homens ao fundo - ceticismo - fortaleceu Schopenhauer, porque ele não era um erudito. O terceiro e último perigo apontado por Nietzsche foi a nostalgia, Schopenhauer teve como adversário mais forte, ele mesmo: "todo homem encontra normalmente em si um limite dos seus dons, assim como do seu querer moral, e este limite o enche de nostalgia e melancolia" (NIETZSCHE, 2003, p.158). Schopenhauer não se entregou à comodidade que o limite impõe, mas pela sua força se superou a partir de si mesmo pela negação, elaborou a tarefa das mais difíceis, segundo Nietzsche, com isso ele se conservou como filósofo no sentido mais forte que esse termo requer.

Após apresentar os perigos que estiveram à sombra de Schopenhauer e como ele se resguardou deles, Nietzsche alerta que "estes três perigos constitutivos que ameaçavam Schopenhauer também nos ameaçam a todos" (NIETZSCHE, 2003, p.159). Daí a importância de Schopenhauer como ideal a ser seguido que, para Nietzsche, somente com o filósofo de Frankfurt se pode aprender a superá-los, não se rendendo ao desencorajamento da melancolia.

Como exemplo de vida, Nietzsche explica que Schopenhauer, contrariamente a de Kant, quase não dava atenção às castas acadêmicas, estava alheio a estas relações, buscava independência em relação à sociedade e também ao Estado. Já Kant, mesmo que sua filosofia fosse bem intencionada, no fundo ele teve limites na sua criatividade, porque permaneceu vinculado à Universidade, "se submeteu aos governantes, salvou as aparências de uma fé religiosa, suportou viver entre colegas e estudantes: é portanto natural que seu exemplo tenha produzido sobretudo professores de filosofia e uma filosofia de professores" (NIETZSCHE, 2003, p.151). Para Nietzsche, em Schopenhauer, encontra-se o exemplo da unidade de estilo, que é tão necessário à cultura autêntica, enquanto que Kant pode representar apenas uma parte.

Outra característica importante em Schopenhauer, para Nietzsche, é que ele não fora preparado e educado para a erudição, mesmo não querendo, ele teve de trabalhar em um escritório comercial e passou sua juventude neste ambiente, o que corrobora com a ideia nietzschiana de que "um erudito não se tornaria jamais um filósofo" (NIETZSCHE, 2003, p.205). 
O filósofo de Frankfurt é, segundo Nietzsche, um dos poucos homens excepcionais, um homem que possui, em sua filosofia, não um se conformar, mas, sim, um agir. Schopenhauer seria o inverso da tendência moderna que supervaloriza a razão lógica que contribui decisivamente para o enfraquecimento da cultura alemã da época, podendo até culminar na sua extirpação. Para Nietzsche, Schopenhauer lembra um pouco Goethe, "pois ele pretende dizer o que é profundo simplesmente, o que é comovente sem retórica, o que é estritamente científico sem pedantismo" (NIETZSCHE, 2003, p.148); além de ser libertador, ao transmitir ensinamentos, tanto na grandeza interior quanto como um estímulo para a ação, deixando como lição a máxima: "Não engane a ninguém, nem mesmo a ti próprio" (NIETZSCHE, 2003, p.147).

Nietzsche considerava Schopenhauer um extemporâneo, porque mesmo estando exposto aos perigos de sua época, ele soube transcender suas enfermidades, não sucumbindo aos interesses do Estado, pois criticava a sua realidade, revelando um mundo temível, que não era guiado por Providência alguma, nem ocupado por Deus, Schopenhauer se portou como seu próprio juiz e se autolegislou, soube reconhecer que sua época não era sua mãe, mas sua madrasta comportou-se, então, como um filho bastardo. Para Nietzsche, Schopenhauer condena a vida, e essa condenação é sustentada em uma inspiração tão ardente, que é a vida, ainda que a se admira e a se descobre.

Nietzsche não defende que o filósofo de Frankfurt possa vir a ser o educador de todos os homens, mas se mostra preocupado como poderia emergir um filósofo com características necessárias para ser um educador e fazer para outros homens aquilo que Schopenhauer fez com ele. Assim, Nietzsche questiona: “onde estão na verdade para todos nós, eruditos e ignorantes, grandes e pequenos, nossas celebridades e nossos modelos morais entre nossos contemporâneos, visível encarnação de toda moral criadora nesta época?" (NIETZSCHE, 2003, p.145). Para o filósofo, a sociedade moderna da Alemanha não tinha tal preocupação, e raramente refletia sobre esta questão, e, quando fazia, era de forma tímida e ingênua.

Para Nietzsche, as instituições de ensino da Alemanha e seus mestres não consideravam qualquer educação, moral, ou quando muito, vivia-se "de fato do capital de moralidade acumulado" (NIETZSCHE, 2003, p.145) dos ancestrais; ou seja, repetiase modelos transmitidos pelos avós e pais que levavam a uma certa comodidade na obediência às normas vigentes, já que para o filosofo, a sociedade alemã de sua época se contentava com o puro formalismo: "a virtude é uma palavra com a qual professores e 
alunos não querem mais pensar nada, uma palavra fora de moda da qual se ri - e é pior ainda quando não se ri, porque então é hipocrisia" (NIETZSCHE, 2003, p.145). Portanto, para o Nietzsche, a Alemanha de sua época precisava urgentemente de educadores morais, mas ao mesmo tempo, nunca foi tão difícil encontrá-los, entendendo como educador moral aquele que não subtrai teoria da prática, que educa justamente por ser um exemplo de vida que reflete sua obra.

Neste sentido, Nietzsche afirmava não ser tão simples explicar a indolência do homem moderno e sua ausência de forças morais, pois mesmo levando em consideração a influência do cristianismo sobre a moral, não se pode ignorar a reação do cristianismo em vias de sucumbir nesses tempos modernos, "pela grandeza do seu ideal, o cristianismo ultrapassou tanto o sistema de moral dos antigos e o sentimento natural que reina uniformemente neles, que ficou insensível" (NIETZSCHE, 2003, p.146), não podendo retornar ao que ele tinha de melhor: a virtude antiga que, no cristianismo dos nossos dias, foi submetida ao otimismo vulgar.

O homem moderno vive neste vaivém entre o cristianismo e a ambigüidade, entre um cristianismo de costumes timorato ou mentiroso e um pensamento segundo o estilo antigo, igualmente sem coragem e confuso consigo mesmo; aqui, ele se encontra mal. (NIETZSCHE, 2003, p.146).

Nietzsche queria chamar a atenção dos jovens para o que é, de fato, importante: a habilidade e a coragem para responder ao chamado de ser você mesmo, não como autoindulgência, mas naquilo que tange à emancipação, "tua essência não está oculta no fundo de ti, mas colocada infinitamente acima de ti” (NIETZSCHE, 2003, p.146).

O filósofo afirma que é necessário que cada indivíduo faça sua própria interpretação de Schopenhauer, para que se convença da sua própria miséria e de seus limites, aprendendo, assim, a conhecer os remédios, ou seja, a renúncia do eu e a sujeição para fins mais nobres, especialmente aqueles da piedade e da justiça. Nietzsche atesta que a impressão causada por Schopenhauer é composta por três elementos:

\footnotetext{
A impressão de sua honestidade, da sua serenidade e da sua constância. Ele é honesto porque fala e escreve por si mesmo e para si mesmo; sereno porque venceu pelo pensamento o que há de mais difícil, e constante porque assim deve ser. Sua força cresce reta e ligeira como uma chama no ar tranqüilo, certa de si, sem tremer, sem inquietude. Em cada uma destas qualidades, ele encontra seu caminho sem que inclusive notemos que ele o tenha procurado; pelo contrário, como movido por uma lei da gravidade, ele aí se lança, firme e ágil, inexorável. (NIETZSCHE, 2003, p.150).
}

A partir daí, Nietzsche teve a certeza de ter encontrado o educador que tanto 
procurava, extraindo, pressupostos para o desenvolvimento do sujeito com o espírito livre, pois Schopenhauer é considerado um extemporâneo, como um autêntico filho de seu tempo soube se opor a ele, criticando e combatendo questões relevantes desta mesma época, atitude esta que, segundo Nietzsche, é a manifestação exemplar da liberdade humana, exemplo de como "podemos nos educar contra o nosso tempo" (NIETSZCHE, 2005, p.163), libertando o sujeito de um pensamento cativo.

\section{Considerações Finais}

Para Nietzsche, é necessário que fiquemos inconformados contra o otimismo da barbárie que colocava o Estado como fim supremo da humanidade, e também contra o utilitarismo que vê na cultura apenas uma forma de ganhar dinheiro. É neste ponto que a imagem de Schopenhauer deve nos encorajar, "o homem de Schopenhauer assume para si o sofrimento voluntário da veracidade e este sofrimento lhe serve para mortificar sua vontade pessoal e preparar a subversão, a total transformação do seu ser". (NIETZSCHE, 2003, p.171). Para Nietzsche, Schopenhauer seria o modelo de filósofo a ser seguido, pois os homens poderiam, por meio de sua filosofia, elevar-se acima da cultura vigente, sua filosofia seria o caminho a trilhar que conduziria o homem a um estágio superior de cultura, ele seria o "verdadeiro filósofo, capaz de elevar alguém acima da insuficiência da atualidade e de ensinar novamente a ser simples e honesto no pensamento e na vida" (NIETZSCHE, 2003, p.146, grifo do autor). Essa afirmação coloca em evidência o projeto nietzschiano de formação de um tipo superior de homem, cujo objetivo é o de criticar a mediocridade da cultura da época, preparando o terreno, para que possa, assim, emergir uma cultura superior e autêntica.

Para Nietzsche, é somente por meio da educação que seria possível a elevação da cultura. $\mathrm{O}$ círculo dos eruditos e de pessoas cultivadas inspiram apenas "repugnância e aversão" (NIETZSCHE, 2003, p.158), pois eles criam obstáculos que impedem a gestação de uma cultura autêntica, e, desta forma, aqueles que pertençam a uma instituição educacional devem preparar o seu entorno, ter cuidado, pois é ele que pode propiciar o florescimento de uma cultura que seja autêntica.

O filósofo pensou e analisou a cultura em suas necessidades vitais e não somente com a finalidade de satisfazer as exigências do Estado e/ou da burguesia mercantil, que enxergava lucro em tudo. Deste modo, Nietzsche adotou a vida como critério essencial para sua crítica aos valores da cultura vigente, atacando as convicções que nutriam o 
sistema educacional da época; pois, tanto a educação quanto a formação são pilares fundamentais para a construção de uma cultura. Para ele, o Estado não pode ser o fim último da cultura, este fim deve ser a vida, mas não a vida moderna - prenúncio de uma crise que já se apresentava gradativamente instituída na vida urbana que se introduzia vagarosamente - mas a vida vivida em sua plenitude.

Em Schopenhauer como educador, Nietzsche em oposição a erudição, apresenta um projeto singular de autoformação. Contudo a concepção de vida se impõe como necessidade para uma educação que visa se emancipar do Estado, que não busque somente formar jovens para se tornarem funcionários burocráticos do Estado, ou apenas bons técnicos para a burguesia mercantil; destarte que o projeto educacional nietzschiano vai para além de educar/formar homens dóceis. Para tanto, Nietzsche apresenta um modelo de educador que pudesse afirmar a vida para levar o sujeito a ser o que se é, e, deste modo, o indivíduo precisa se responsabilizar de ser ele mesmo e não ser somente um apêndice na constituição da massa.

Para Nietzsche, o educador deve ter a incumbência de libertar o indivíduo em todas as suas possibilidades, para avaliar, agir e interpretar; pois apenas o sujeito livre do cientificismo e dos interesses do Estado poderia abandonar a pseudocultura. É importante ressaltar que a crítica nietzschiana se estende também aos professores desses estabelecimentos, principalmente aos de filosofia, que ele denominou de filósofos de profissão, já que estes não incentivavam seus alunos à refletirem a respeito das coisas humanas e sobre a vida; pois, o que eles faziam era reproduzir a história da filosofia. Assim, Nietzsche percebeu que sua época precisaria de educadores verdadeiros e sugeriu que quem melhor desempenharia esta função seriam os filósofos, mas não aqueles que faziam dela um ganha-pão, mas verdadeiros filósofos como Schopenhauer.

\section{Referências}

MELO SOBRINHO, N. C. Apresentação: a pedagogia de Nietzsche. In: NIETSZCHE, F. Escritos sobre educação: Friedrich Nietzsche. São Paulo: Loyola, 2003.

NIETZSCHE, F. II consideração intempestiva sobre a utilidade e os inconvenientes da história para a vida. Tradução de Nóeli Correia de Melo Sobrinho. In: Escritos sobre história: Friedrich Nietzsche. São Paulo: Edições Loyola, 2005.

III Consideração intempestiva: Schopenhauer educador. Tradução de Nóeli Correia de Melo Sobrinho. In Escritos sobre educação: Friedrich Nietzsche. São Paulo: Loyola, 2003. 
Consideraciones intempestivas, I: David Strauss, el confessor y el el escritor (y fragmentos póstumos). Tradução de Andrés Sánchez Pascual. Madrid: Alianza Editorial, 2000.

PASCHOAL, A. Nietzsche: a boa forma de retribuir ao mestre. Revista de Filosofia Aurora, Curitiba, v.20, n. 27, p.337-350, jul/dez. 2008. 